\title{
Beutenbergia cavernae gen. nov., sp. nov., an L-lysine-containing actinomycete isolated from a cave
}

\author{
Ingrid Groth, ${ }^{1}$ Peter Schumann, ${ }^{2}$ Barbara Schuetze, ${ }^{1}$ Kurt Augsten, ${ }^{3}$ \\ Ina Kramer ${ }^{2}$ and Erko Stackebrandt ${ }^{2}$
}

1 Hans-Knöll-Institut für Naturstoff-Forschung e.V., D-07745 Jena, Germany

2 DSMZ - Deutsche Sammlung von Mikroorganismen und Zellkulturen $\mathrm{GmbH}$, D-38124 Braunschweig, Germany

3 Institut für Molekulare Biotechnologie e.V., D-07745 Jena, Germany

\author{
Author for correspondence: Ingrid Groth. Tel: +4936416566 66. Fax: +493641656679 \\ e-mail: igroth@pmail.hki-jena.de
}

\begin{abstract}
Two aerobic, Gram-positive bacteria, strains HKI $0122^{\top}$ and HKI 0132, were isolated from a cave. Cells are not acid-fast, non-motile, non-spore-forming and exhibit a rod-coccus growth cycle. The cell wall peptidoglycan contains lysine in position 3 of the peptide subunit and an interpeptide bridge of L-Lys $\leftarrow$ L-Glu. The major menaquinone is MK-8 $\left(\mathrm{H}_{4}\right), 13-$ methyl and 12-methyl tetradecanoic acids are the predominating fatty acids. The polar lipids consist of phosphatidylinositol, diphosphatidylglycerol and three unknown phospholipids. Mycolic acids are absent. The DNA base composition is $71 \mathrm{~mol} \%$

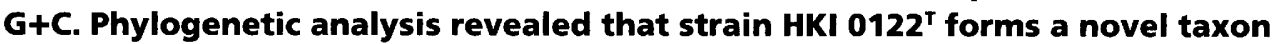
among the families and unassigned genera of the suborder Micrococcineae, within the order Actinomycetales. On the basis of the genotypic, chemotaxonomic, morphological and physiological characteristics of these two isolates it is proposed to assign strains HKI $0122^{\top}$ and HKI 0132 to a new genus and species for which the name Beutenbergia cavernae gen. nov., sp. nov. is proposed. The type strain is HKI $0122^{\top}$ (= DSM 12333').
\end{abstract}

Keywords: Beutenbergia cavernae gen. nov., sp. nov., L-lysine-containing actinomycete

\section{INTRODUCTION}

The microbial diversity of as yet poorly studied biotopes is being increasingly explored by molecular detection methods and classical isolation techniques (Eppard et al., 1996; Rheims et al., 1996, 1998; Rainey, 1998; Waite et al., 1998). While molecular methods are valuable tools in characterizing the microflora, isolation and culturing are required for describing the microbial diversity, especially in cases of novel taxa (Palleroni, 1997). Isolation procedures performed recently in karstic caves of northern Spain and southern Italy (Groth \& Saiz-Jimenez, 1999; Groth et al., 1999) revealed the occurrence of many different genera of actinomycetes. Applying similar isolation methods to a soil sample collected in the Reed Flute Cave near Guilin, Guangxi (China) two strains were found that were characterized by the common occurrence of the two chemotaxonomic properties, i.e. lysine as diagnostic diamino acid in the peptidoglycan and MK-

The EMBL accession number for the $16 \mathrm{~S}$ rDNA sequence of $\mathrm{HKI} 0122^{\top}$ is Y18378.
$8\left(\mathrm{H}_{4}\right)$ as the main menaquinone. Within the class Actinobacteria (Stackebrandt et al., 1997) this combination of taxonomic markers has so far only been found in members of the genera Bogoriella (Groth et al., 1997a) and Demetria (Groth et al., 1997b). Similarity values of $16 \mathrm{~S}$ rDNA sequences obtained for the type strains of these two genera, for other representatives of members of the order Actinomycetales and for the two cave isolates, showed the latter to be neither related to the genera Bogoriella or Demetria nor to any other genus of the order Actinomycetales. This distinct phylogenetic position was supported by chemotaxonomic, physiological and morphological characteristics.

On the basis of our results we concluded that both strains should be classified in a new genus and species for which the name Beutenbergia cavernae is proposed. The type strain is HKI $0122^{\mathrm{T}}$ (DSM $\left.12333^{\mathrm{T}}\right)$.

\section{METHODS}

Bacterial strains and cultural conditions. Strains HKI $0122^{\mathrm{T}}$ and HKI 0132 were isolated from a soil sample collected in a cleft between the rocks of the Reed Flute Cave near Guilin, 


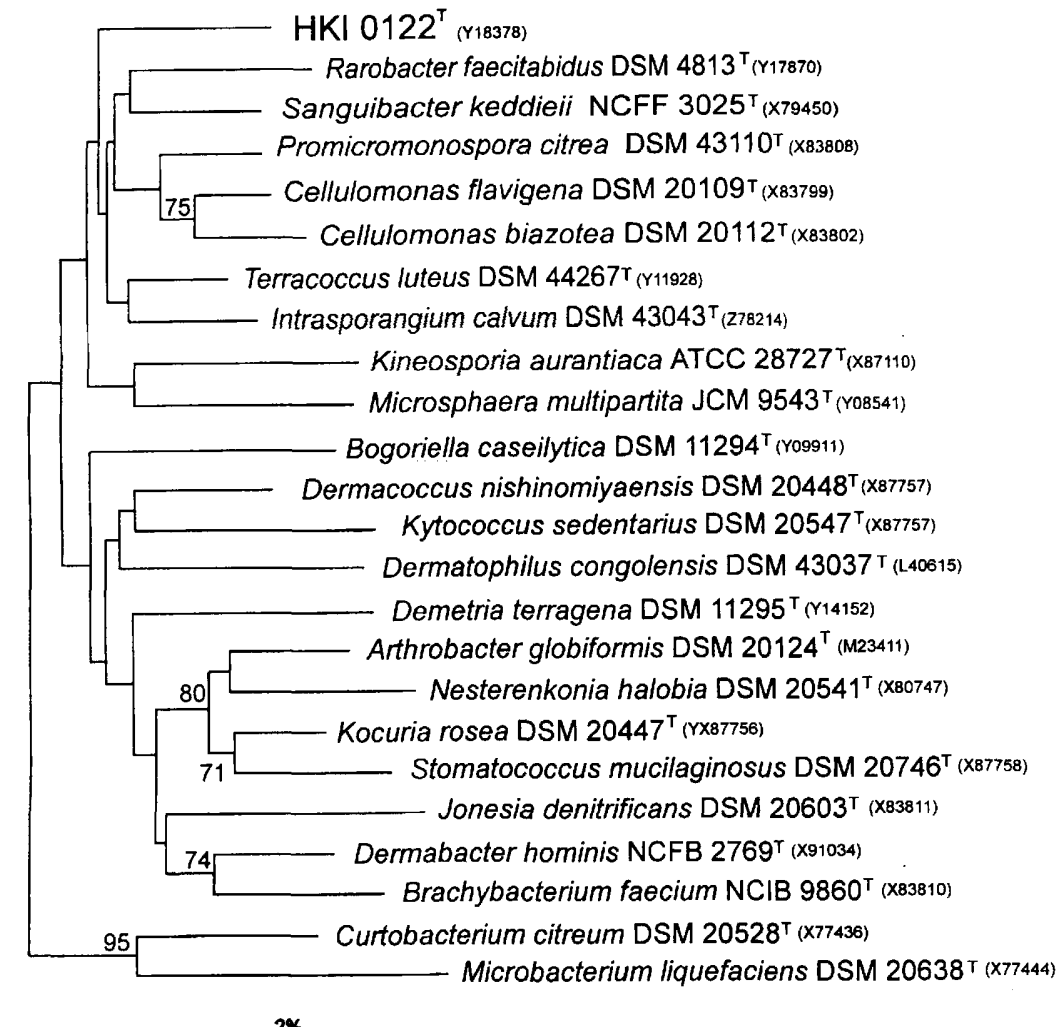

Fig. 1. $16 \mathrm{~S}$ rDNA sequence-based phylogenetic dendrogram constructed from evolutionary distances (De Soete, 1983) showing the phylogenetic position of strain HKI $0122^{\top}$ next to members of the family Intrasporangiaceae and of other families of the suborder Micrococcineae (Stackebrandt et al, 1997). Numbers at branching points refer to bootstrap values (500 trees resampled). Scale bar, 2 inferred nucleotide substititions per 100 nucleotides.
Guangxi (China). One gram of soil was suspended in $10 \mathrm{ml}$ sterile phosphate buffer (pH 7.2) and thoroughly mixed by shaking. Soil particles were allowed to sediment, the liquid phase was serially diluted and spread onto the surface of casein mineral medium (Altenburger et al., 1996) which contains per litre: $0.6 \mathrm{~g} \mathrm{~K}_{2} \mathrm{HPO}_{4}, 0.5 \mathrm{~g} \mathrm{Na}_{2} \mathrm{HPO}_{4} .2 \mathrm{H}_{2} \mathrm{O}$, $0.05 \mathrm{~g} \mathrm{MgSO}_{4} .7 \mathrm{H}_{2} \mathrm{O}, 0.1 \mathrm{~g} \mathrm{MgCl}_{2} .7 \mathrm{H}_{2} \mathrm{O}, 0.2 \mathrm{~g} \mathrm{KNO}_{3}$, $0.01 \mathrm{~g} \mathrm{FeCl}_{3} .6 \mathrm{H}_{2} \mathrm{O}, 0 \cdot 8 \mathrm{~g}$ casein and $0.4 \mathrm{~g}$ yeast extract $(\mathrm{pH}$ $7 \cdot 0$ ) and peptone/yeast extract/brain-heart infusion medium (Yokota et al., 1993) in the case of HKI 0132. Solidified rich (R) medium (Yamada \& Komagata, 1972) was used for general laboratory cultivation including morphological and physiological studies unless otherwise indicated. Biomass for biochemical analyses was prepared by cultivating the strains in liquid R medium or Bacto tryptic soy broth (Difco) and harvesting the cells by centrifugation.

Morphological and physiological characteristics. Cell morphology was examined by phase-contrast microscopy (Olympus BH-2 microscope). Motility was studied by the hanging drop technique. Cell dimensions were measured microscopically [Olympus BX 50, equipped with the image analysing software VIS $5504 \mathrm{H}$ (Jentech)]. Gram staining and acid-fast staining were performed as described previously (Groth et al,, 1997b). For scanning electron microscopy, a 72-h-old culture grown on a $\mathbf{R}$ agar plate was suspended in phosphate buffer ( $\mathrm{pH} 7 \cdot 2)$. Preparation of cells was as described by Groth et al. (1997b). Cell morphology was studied with a field emission scanning electron microscope (LED 1530) with a working distance of $3 \mathrm{~mm}$. Colony morphology was studied with a stereo microscope (Olympus $S Z$ 11). Growth dependence on different incubation temperatures, increasing concentrations of $\mathrm{NaCl}$ in the culture medium and on the supply with oxygen as well as the utilization of various organic compounds and selected enzyme activities were studied as described by Groth et al. (1997b). The susceptibility to antibiotics was tested with antibiotic discs (Oxoid) on $\mathrm{R}$ agar plates seeded with suspensions of HKI $0122^{\mathrm{T}}$ and HKI 0132, respectively.

Cell wall analysis. Purified cell wall preparations were obtained by the method of Schleifer \& Kandler (1972). The amino acids and peptides in cell wall hydrolysates were analysed by two-dimensional ascending TLC on cellulose plates using the solvent systems of Schleifer \& Kandler (1972). The amino terminal amino acid of the interpeptide bridge was determined by dinitrophenylation as described by Schleifer (1985). Whole-cell sugars were determined as alditol acetates by GC as described by Groth et al. (1996). The molar ratios of amino acids were determined by GC and GC-MS of $N$-heptafluorobutyryl amino acid isobutyl esters (MacKenzie, 1987). Analysis of enantiomers of cell wall amino acids was performed by $\mathrm{GC}$ of $N$-pentafluoropropionyl amino acid isopropyl esters (Frank et al., 1980) on a L-Chirasil-Val column $(25 \mathrm{~m} \times 0.25 \mathrm{~mm}$ i.d.; MachereyNagel) using helium as carrier gas at a linear velocity of $200 \mathrm{~mm} \mathrm{~s}^{-1}$ and at a temperature programmed from 80 to $190{ }^{\circ} \mathrm{C}$ at a rate of $2{ }^{\circ} \mathrm{C} \mathrm{min}-1$. Instruments used for $\mathrm{GC}$ and GC-MS were as specified previously (Groth et al., 1996). The glycolate content of bacterial cell walls was determined by the colorimetric method of Uchida \& Aida (1984).

Lipid analysis. Cellular fatty acid methyl esters obtained from cells grown in Bacto tryptic soy broth at $28^{\circ} \mathrm{C}$ by the method of Stead et al. (1992) were separated by GC (Groth et al, , 1996) and identified as described previously (Schumann et al., 1997). Menaquinones were extracted as described by Collins et al. (1977) and were analysed by HPLC (Groth et al., 1997a). Polar lipids extracted by the method of Minnikin et al. (1979) were identified by two- 
dimensional TLC and spraying with specific reagents (Collins \& Jones, 1980). Absence of mycolic acids was demonstrated by TLC (Minnikin et al., 1975).

DNA base composition. DNA was isolated and its $\mathrm{G}+\mathrm{C}$ content determined by HPLC of deoxyribonucleosides as described by Groth et al. (1996).

165 rDNA sequence determination and phylogenetic analysis. Preparation of genomic DNA from strains HKI $0122^{1}$ and HKI 0132 was done as described previously (Rainey et al., 1996). Sequences were aligned manually with sequences published previously. These were stored in the DSMZ 16S rDNA database consisting of several thousand 16S rDNA sequence entries, including those from the Ribosomal Database Project (Maidak et al., 1997) and EMBL. Similarity values were transformed into phylogenetic distance values that compensate for multiple substitutions at any given site in the sequence (Jukes \& Cantor, 1969). The algorithm of De Soete (Maidak et al., 1997) and the neighbour-joining and the maximum-likelihood methods contained in the PHYLIP package (Felsenstein, 1993) were used in the construction of phylogenetic dendrograms. Bootstrap values were determined according to Felsenstein (1993). All analyses were done on a SUN SparcII workstation.

Nucleotide accession numbers. The accession numbers of the reference strains used in the phylogenetic analysis are shown in Fig. 1.

\section{RESULTS}

\section{Morphological and physiological characteristics}

Colonies of strain HKI $0122^{\mathrm{T}}$ grown on R agar plates were circular, glistening, convex, smooth, opaque with an entire margin. They varied in colour from cream to bright yellow. The diameters of the colonies were in the range $0.7-1.8 \mathrm{~mm}$. During growth in complex media a rod-coccus growth cycle occurred. Young cultures (about $24 \mathrm{~h}$ ) were composed almost entirely of irregular rods arranged in palisades, clusters or in pairs at an angle to give V-forms (Fig. 2a). In stationaryphase cultures coccoid cells dominated occurring singly, in pairs, irregular clusters and short chains (Fig. $2 b$ ). After transfer to fresh medium coccoid cells grew out to give rise to irregular slightly curved rods. Cells were heterogeneous in their sizes. Rods varied from 1.0 up to $3.1 \mu \mathrm{m}$ in length and had a width of about $0.5-0.8 \mu \mathrm{m}$. The diameters of the cocci were $0.7-$ $1.0 \mu \mathrm{m}$. The heterogeneity of the cells was additionally demonstrated by scanning electron microscopy (Fig. $3)$. Spore formation and motile cells were not observed.

The cells of strain HKI $0122^{\mathrm{T}}$ stained Gram-positive and were not acid-fast according to Ziehl-Neelsen staining.

Strain HKI $0122^{\mathrm{T}}$ grew well on complex organic media at $28^{\circ} \mathrm{C}$ under aerobic and microaerophilic conditions. Growth was much reduced at $37^{\circ} \mathrm{C}$ and did not occur at $42{ }^{\circ} \mathrm{C}$ nor under an anaerobic atmosphere, respectively. Restricted growth was observed on $\mathrm{R}$ agar with $2-4 \%(w / v)$ of $\mathrm{NaCl}$. Growth was completely inhibited by the presence of $6 \%(\mathrm{w} / \mathrm{v})$ of $\mathrm{NaCl}$ in the
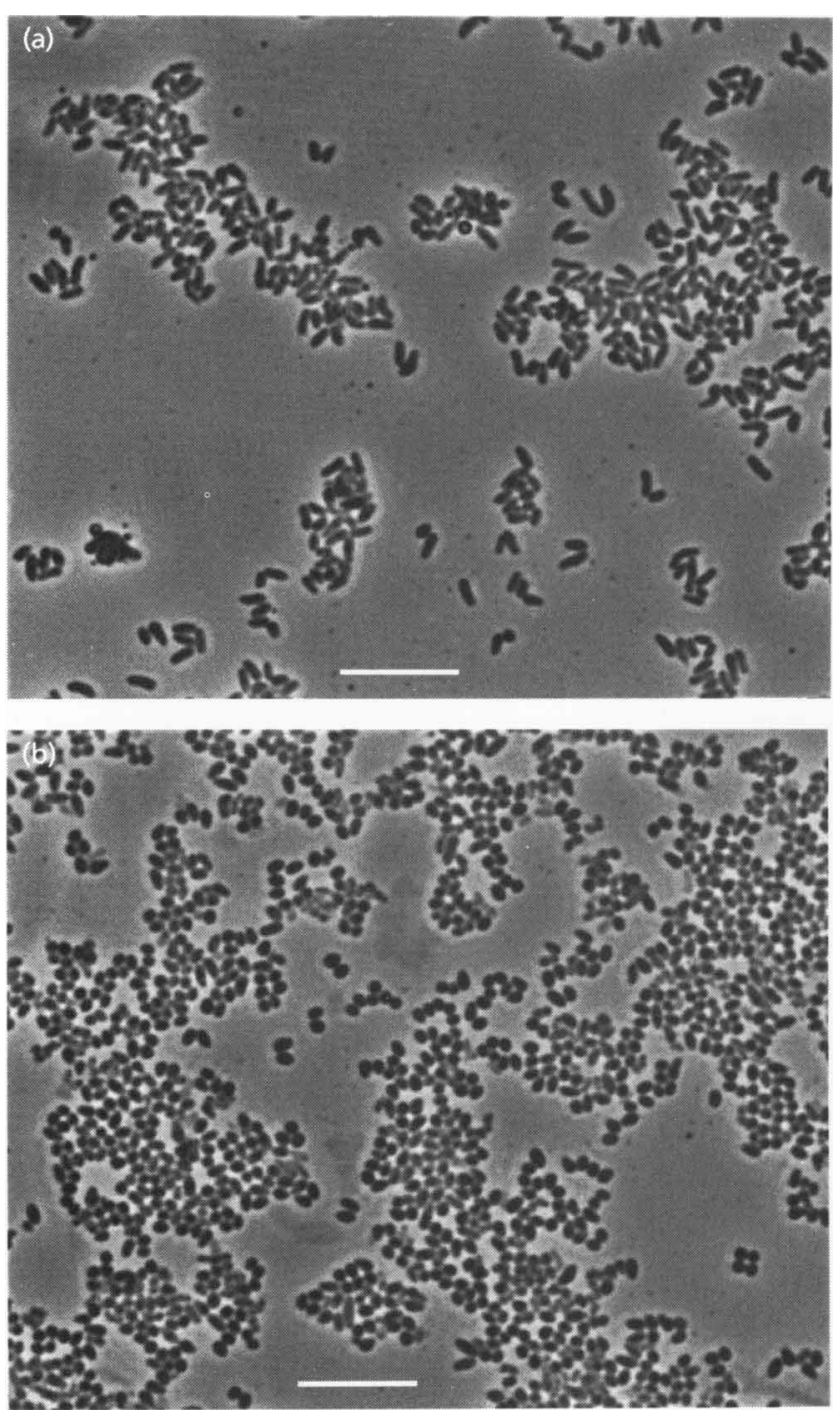

Fig. 2. Micrographs of strain $H K I 0122^{\top}$ grown at $28^{\circ} \mathrm{C}$ in liquid $\mathrm{R}$ medium for (a) $24 \mathrm{~h}$ or (b) $96 \mathrm{~h}$. Bars, $10 \mu \mathrm{m}$.

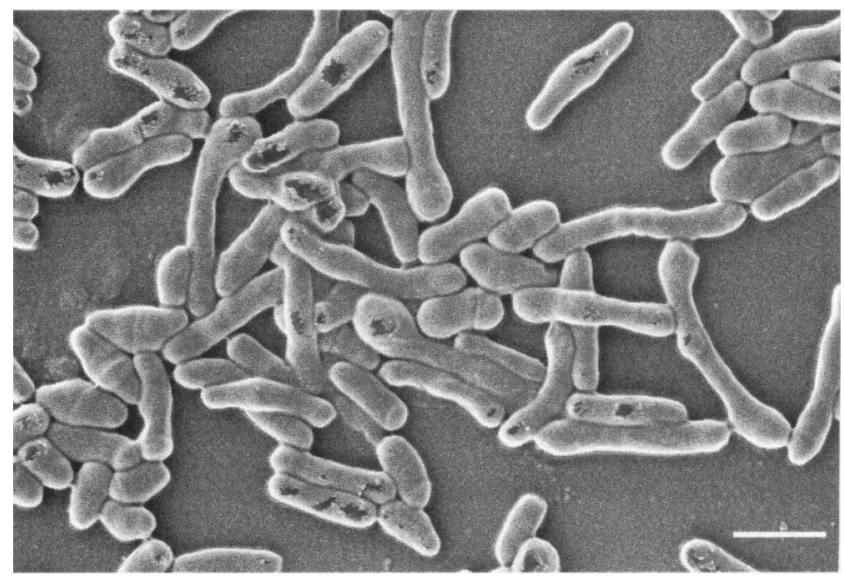

Fig. 3. Scanning electron micrograph of cells from a 72-h-old culture of strain HKI $0122^{\top}$ grown on R agar. Bar, $1 \mu \mathrm{m}$. 
Table 1. Physiological properties of strain HKI $0122^{\top}$

-, Negative; + , positive; w, weakly positive.

\begin{tabular}{|c|c|c|c|c|c|}
\hline Test & Result & Test & Result & Test & Result \\
\hline Decomposition of: & & Utilization of : & & Growth in the presence of: & \\
\hline Adenine & - & Acetate & - & $2 \% \mathrm{NaCl}$ & + \\
\hline Casein & + & Aconitate & - & $4 \% \mathrm{NaCl}$ & + \\
\hline Esculin & + & Benzoate & - & $6 \% \mathrm{NaCl}$ & - \\
\hline Gelatin & + & Citrate & - & Growth at: & \\
\hline Hippurate & - & Formate & - & $28^{\circ} \mathrm{C}$ & + \\
\hline Hypoxanthine & - & Malate & - & $37^{\circ} \mathrm{C}$ & w \\
\hline Potato starch & w & Succinate & - & $42^{\circ} \mathrm{C}$ & - \\
\hline Tween 80 & - & DL-Tartrate & - & Antibiotic susceptibility: & \\
\hline Tyrosine & - & Enzyme assay (API ZYM) & & Ampicillin, $10 \mu \mathrm{g}$ & + \\
\hline Urea & - & Phosphatase alkaline & + & Chloramphenicol, $30 \mu \mathrm{g}$ & + \\
\hline Xanthine & - & Esterase (C 4) & + & Ciprofloxasin, $5 \mu \mathrm{g}$ & - \\
\hline Acid produced from: & & Esterase lipase (C 8) & + & Erythromycin, $15 \mu \mathrm{g}$ & + \\
\hline L-Arabinose & + & Lipase (C 14) & - & Gentamicin, $10 \mu \mathrm{g}$ & - \\
\hline Lactose & - & Leucine arylamidase & + & Kanamycin, $30 \mu \mathrm{g}$ & - \\
\hline D-Cellobiose & + & Valine arylamidase & - & Lincomycin, $2 \mu \mathrm{g}$ & - \\
\hline Dextrin & + & Cystine arylamidase & + & Neomycin, $30 \mu \mathrm{g}$ & + \\
\hline D-Fructose & + & Trypsin & - & Nitrofuran, $300 \mu \mathrm{g}$ & - \\
\hline D-Galactose & + & Chymotrypsin & - & Oxacillin, $5 \mu \mathrm{g}$ & - \\
\hline D-Glucitol & - & Phosphatase acid & + & Oxytetracycline, $30 \mu \mathrm{g}$ & + \\
\hline D-Glucose & + & Naphthol-AS-BI- & + & Penicillin, 2 IU & + \\
\hline Glycerol & + & phosphohydrolase & & Polymyxin B, 300 IU & $\mathbf{w}$ \\
\hline Inulin & + & $\alpha$-Galactosidase & + & Rifampin, $2 \mu \mathrm{g}$ & + \\
\hline Maltose & + & $\beta$-Galactosidase & + & Streptomycin, $10 \mu \mathrm{g}$ & - \\
\hline D-Mannitol & - & $\beta$-Glucuronidase & - & Sulfonamide, $300 \mu \mathrm{g}$ & - \\
\hline D-Mannose & + & $\alpha$-Glucosidase & + & Nitrate reduction & + \\
\hline D-Raffinose & + & $\beta$-Glucosidase & - & Production of $\mathrm{H}_{2} \mathrm{~S}$ & + \\
\hline L-Rhamnose & + & $N$-Acetyl- $\beta$-glucosamidase & + & Catalase reaction & + \\
\hline D-Ribose & + & $\alpha$-Mannosidase & + & Methyl red test & - \\
\hline Salicin & + & $\alpha$-Fucosidase & + & Voges-Proskauer test & - \\
\hline Sucrose & + & & & Oxidase test & - \\
\hline Potato starch & + & & & Indole test & - \\
\hline Trehalose & + & & & & \\
\hline D-Xylose & + & & & & \\
\hline
\end{tabular}

agar. Long-term storage was performed in the vapour phase of liquid nitrogen by adding $5 \%(\mathrm{w} / \mathrm{v})$ of DMSO to the culture broth.

The physiological properties of strain HKI $0122^{\mathrm{T}}$ are listed in Table 1.

\section{Cell wall analysis}

The peptidoglycan of strain HKI $0122^{\mathrm{T}}$ contained Ala, Glu and Lys in a molar ratio of $2 \cdot 1: 2 \cdot 2: 1 \cdot 0$. Dinitrophenylated Glu was detected in hydrolysates of cell wall preparations treated with 1-fluoro-2,4dinitrobenzene. Enantiomeric analysis of cell wall amino acids resulted in detection of D-Ala, L-Ala, D-
Glu, L-Glu and L-Lys. From these results and from two-dimensional thin-layer chromatographic peptide patterns of partial hydrolysates of cell walls (data not shown), it was concluded that strain HKI $0122^{\mathrm{T}}$ contains a peptidoglycan of type A $4 \alpha$ (Schleifer \& Kandler, 1972) with an L-Lys $\leftarrow$ L-Glu interpeptide bridge [murein type A11.54 (DSMZ, 1998)]. The acyl type was acetyl. The whole-cell sugars were glucose, mannose and galactose.

\section{Lipid analysis}

The polar lipid patterns consisted of phosphatidylinositol, diphosphatidylglycerol and three unknown phospholipids. The cellular fatty acid profiles were of 
iso and anteiso branched type and were distinctly dominated by the occurrence of 13-methyl and 12methyl tetradecanoic acids. The percentages of fatty acid composition of strain HKI $0122^{\mathrm{T}}$ are as follows : $\mathrm{i}-$ $\mathrm{C}_{14: 0}, 0.9 ; \mathrm{C}_{14: 0}, 1.9 ; \mathrm{i}-\mathrm{C}_{15: 0}, 43 \cdot 7 ;$ ai- $\mathrm{C}_{15: 0}, 34 \cdot 6 ; \mathrm{C}_{15: 0}$, $0.9 ; \mathrm{i}-\mathrm{C}_{16: 0}, 2 \cdot 3 ; \mathrm{C}_{16: 0}, 6 \cdot 8 ; \mathrm{i}-\mathrm{C}_{17: 0}, 3 \cdot 1 ;$ ai- $\mathrm{C}_{17: 0}, 4.9$; $\mathrm{C}_{18: 1}, 0.9$ (note: $\mathrm{C}_{16: 0}$, hexadecanoic acid; $\mathrm{C}_{18: 1}$, octadecenoic acid; $\mathrm{i}-\mathrm{C}_{15: 0}$, 13-methyl tetradecanoic acid; ai- $\mathrm{C}_{17: 0}, 14$-methyl hexadecanoic acid).

The major menaquinone was $\mathrm{MK}-8\left(\mathrm{H}_{4}\right) . \mathrm{MK}-8\left(\mathrm{H}_{2}\right)$, MK-8 and MK-9 $\left(\mathrm{H}_{4}\right)$ occurred in minor amounts. Mycolic acids were not present.

\section{DNA base composition}

Strain HKI $0122^{\mathrm{T}}$ had a DNA $\mathrm{G}+\mathrm{C}$ content of $71 \mathrm{~mol} \%$.

\section{5 rDNA analyses}

The almost complete 16S rDNA sequence, consisting of 1485 nucleotides $(96.3 \%$ of the Escherichia coli sequence) was determined for strain HKI $0122^{\mathrm{T}}$. A $16 \mathrm{~S}$ rDNA stretch of 530 nucleotides determined for strain HKI 0132 which was isolated from the same cave from which strain HKI $0122^{\mathrm{T}}$ was isolated, showed $100 \%$ sequence similarity to the homologous region of the 16S rDNA of the latter strain. Comparison of the sequence of strain HKI $0122^{\mathrm{T}}$ with those of the members of the order Actinomycetales revealed that this strain is a phylogenetic member of the suborder Micrococcineae (Stackebrand tet al., 1997), with which strain HKI $0122^{\mathrm{T}}$ shared between $90 \%$ (with Brevibacterium linens) and $95 \%$ (with Promicromonospora enterophila) similarity. The sequence of strain HKI $0122^{\mathrm{T}}$ possesses all of the signature nucleotides described to define members of this suborder (Stackebrandt et al., 1997). Similarity values determined with sequences of members of the various families within this suborder ranged from 91.7 to $93 \cdot 1$ (Dermatophilaceae), 91.7 to 93.6 (Microbacteriaceae), 91.7 to 94.2 (Micrococcaceae) and 92.9 to 95.0 (Cellulomonadaceae). In this connection it should be noted, that the nucleotide pair $\mathrm{U}-\mathrm{U}$ given for the position 598-640 for members of the family Micrococcaceae is not a signature but an error and should be corrected to U-G (Stackebrandt et al., 1997).

The lack of high similarity values is consistent with the finding that strain HKI $0122^{\mathrm{T}}$ shares only between 9 and $59 \%$ of signature nucleotides that phylogenetically define families within the suborder Micrococcineae. The highest values were with members of the families Cellulomonadaceae $(59 \%)$ and Intrasporangiaceae $(56 \%)$, indicating that the isolate HKI $0122^{\mathrm{T}}$ does not belong to any of the genera contained in these families. Phylogenetic analysis of strain HKI $0122^{\mathrm{T}}$ and the chemotaxonomically similar species Demetria terragena DSM $11295^{\mathrm{T}}$ and Bogoriella caseilytica DSM $11294^{\mathrm{T}}$ revealed 91.6 and $93.0 \% 16 \mathrm{~S}$ rDNA sequence similarities, respectively.

\section{DISCUSSION}

Lysine in position 3 of the peptide subunit of the peptidoglycan is widely distributed among actinomycetes representing distinct phylogenetic groups. The peptidoglycan type A11.54 (DSMZ, 1998) with the interpeptide bridge L-Lys $\leftarrow$ L-Glu is only described for Arthrobacter sulfureus (Stackebrandt et al., 1983). Although it was found that strain HKI $0122^{\mathrm{T}}$ has the same structure of the interpeptide bridge and an Arthrobacter-like cell and colony morphology there were pronounced differences in the $\mathrm{G}+\mathrm{C}$ content of the DNA, the menaquinone type, the composition of phospholipids and the fatty acid profile between these two taxa (Table 2). These differences justify the separation of strain HKI $0122^{\mathrm{T}}$ from $A$. sulfureus at the genus level which is in agreement with the phylogenetic positions of strain HKI $0122^{\mathrm{T}}$ and the Arthrobacter cluster (Fig. 1). Assessment of the phylogenetic position of strain HKI $0122^{\mathrm{T}}$ within the radiation of a varying selection of reference organisms, using the formula of De Soete (Maidak et al., 1997) the neighbour-joining (NJ) method and the maximumparsimony method (Felsenstein, 1993), consistently showed this strain to branch outside the radiation of any of the defined families of the suborder Micrococcineae. Differences among the phylogenetic trees are seen in the branching points of deeply rooting lineages without, however, changing the genus position of the genera within the individual families. As noted by Stackebrandt et al. (1997) almost none of the branching points among actinobacterial families is supported by high bootstrap values; this phenomenon extends even to some intrafamily relationships when the radiation of lineages occurs within a short evolutionary time span (Stackebrandt et al., 1997). The branching point of strain HKI $0122^{\mathrm{T}}$ is depicted in the distance matrix dendrogram (Fig. 1), generated by the formula of De Soete (1983).

Strain HKI $0122^{\mathrm{T}}$ is unrelated to the genera Bogoriella (Groth et al., 1997a) and Demetria (Groth et al., 1997b) with which it has in common lysine as the diagnostic diamino acid of the peptidoglycan and menaquinones of the MK- $8\left(\mathrm{H}_{4}\right)$ type. This separateness is supported by morphological, physiological and chemotaxonomic characteristics such as the composition of phospholipids and fatty acids (Table 1).

Two unnamed isolates from a medieval wall painting are a further example for the common occurrence of lysine and the menaquinone type $\mathrm{MK}-8\left(\mathrm{H}_{4}\right)$ (Altenburger et al., 1996). These two strains are similar to isolate HKI $0122^{\mathrm{T}}$ in morphological and some chemotaxonomic features. However, their phylogenetic position, which was calculated on the basis of $900 \mathrm{bp}$ of the $16 \mathrm{~S}$ rDNA, reveals the highest degree of similarity to Rathayibacter rathayi $(94.9 \%)$, family Microbacteriaceae. Therefore a close relationship between these isolates and strain HKI $0122^{\mathrm{T}}$ is excluded.

Neither the genotypic nor phenotypic characteristics 
Table 2. Differential characteristics of strain $H K I 0122^{\top}$ and selected taxa with murein type A4 $\alpha$

Abbreviations: L-Ala, L-alanine; D-Asp, D-asparagine; L-Glu, L-glutamic acid; L-Lys, L-lysine; L-Ser, L-serine; DPG, diphosphatidylglycerol; PE, phosphatidylethanolamine; PG, phosphatidylglycerol; PI, phosphatidylinositol; PL, unknown phospholipid; A, anteiso methyl-branched; I, iso methyl-branched; S, straight-chain saturated; U, monounsaturated.

\begin{tabular}{|c|c|c|c|c|c|c|}
\hline Taxon & Cell morphology & $\begin{array}{c}\mathbf{G}+\mathbf{C} \text { content } \\
(\mathrm{mol} \%)\end{array}$ & Interpeptide bridge & Major menaquinone(s) & Polar lipids & $\begin{array}{c}\text { Fatty acid } \\
\text { types }\end{array}$ \\
\hline HKI $0122^{\mathrm{T}}$ & Rod-coccus cycle, non-sporulating & 71 & 1-Lys $\leftarrow$ L-Glu & $\mathrm{MK}-8\left(\mathrm{H}_{4}\right)$ & PI, DPG, 3 PL & $\mathrm{S}, \mathrm{A}, \mathbf{I}$ \\
\hline Bogoriella* & $\begin{array}{l}\text { Irregular rods, coccoid, } \\
\text { non-sporulating }\end{array}$ & 70 & $\begin{array}{l}\text { L-Lys } \leftarrow \text { L-Ala } \leftarrow \text { L-Ala } \leftarrow \text { L- } \\
\text { Glu }\end{array}$ & MK $-8\left(\mathrm{H}_{4}\right)$ & PG, DPG, PI, 1 PL & $\mathrm{A}, \mathrm{I}$ \\
\hline Demetriat & $\begin{array}{l}\text { Coccoid, short rods, } \\
\text { non-sporulating }\end{array}$ & 66 & L-Lys $\leftarrow$ L-Ser $\leftarrow D-A s p$ & $\mathrm{MK}-8\left(\mathrm{H}_{4}\right)$ & PI, PG, DPG, PE, 2 PL. & $\mathrm{S}, \mathrm{U}, \mathrm{A}, \mathrm{I}$ \\
\hline Arthrobacter sulfureus $\ddagger$ & $\begin{array}{l}\text { Rod-coccus cycle, rods } \\
\text { motile or non-motile, } \\
\text { non-sporulating }\end{array}$ & $64-66$ & L-Lys $\leftarrow$ L-Glu & MK-9 or MK-9, MK-10 & PG, DPG, 1 PL & $\mathrm{S}, \mathrm{U}, \mathrm{A}, \mathrm{I}$ \\
\hline
\end{tabular}

* Data from Groth et al. (1997a).

† Data from Groth et al. (1997b).

† Data from Stackebrandt et al. (1983).

of strain HKI $0122^{\mathrm{T}}$ support an affiliation to a currently described genus or a family within the order Actinomycetales. Therefore we propose to classify strain HKI $0122^{\mathrm{T}}$ in a new genus and species for which the name Beutenbergia cavernae gen. nov., sp. nov. is proposed. At this time we do not want to place the new genus in a new family, as the morphological and chemotaxonomic diversity, as well as the $16 \mathrm{~S}$ rDNA signature nucleotides of single species cannot define the phylogenetic depth and width of a higher taxon.

\section{Description of Beutenbergia gen. nov.}

Beutenbergia (Beu'ten.berg.ia. -ia suffix to denote a locality; M.L. fem. n. Beutenbergia referring to Beutenberg, the geographical location of the institute in which the soil sample was studied).

Cells are irregular rods and cocci occurring singly, in pairs, short chains or clusters and exhibit a rod-coccus growth cycle. Cell sizes in rods vary from $1 \cdot 0$ to $3 \cdot 1 \mu \mathrm{m}$ in length. The diameters of the cocci are $0 \cdot 7-1 \cdot 0 \mu \mathrm{m}$. Gram-positive, not acid-fast, non-motile, no formation of spores. Aerobic to microaerophilic. Oxidasenegative, catalase-positive. The peptidoglycan type is A $4 \alpha$ with L-Lys $\leftarrow$ L-Glu as interpeptide bridge. The acyl type is acetyl. The major menaquinone is $\mathrm{MK}$ $8\left(\mathrm{H}_{4}\right)$. The major fatty acids are 13-methyl and 12methyl tetradecanoic acids. The polar lipids are phosphatidylinositol, diphosphatidylglycerol and three unknown phospholipids. The $\mathrm{G}+\mathrm{C}$ content of the DNA is $71 \mathrm{~mol} \%$. Phylogenetically, the genus is a member of the suborder Micrococcineae, order Actinomycetales. The type species is Beutenbergia cavernae.

\section{Description of Beutenbergia cavernae sp. nov.}

Beutenbergia cavernae (ca.ver'nae. L. masc. n. cavus cave; M.L. gen. fem. n. cavernae of a cave, referring to the habitat of the organism).
Cells are irregular rods and cocci occurring singly, in pairs, short chains or clusters and exhibit a rod-coccus growth cycle. Cell sizes in rods vary from $1 \cdot 0$ to $3 \cdot 1 \mu \mathrm{m}$ in length. The diameters of the cocci are $0.7-1 \cdot 0 \mu \mathrm{m}$. Gram-positive, not acid-fast, non-motile, no formation of spores. Aerobic to microaerophilic. Oxidasenegative, catalase-positive. Colonies are $0.7-1.8 \mathrm{~mm}$ in diameter, cream to bright yellow coloured, circular, convex. Acids are produced from L-arabinose, Dcellobiose, dextrin, D-fructose, D-galactose, D-glucose, glycerol, inulin, maltose, D-mannose, D-raffinose, Lrhamnose, D-ribose, salicin, sucrose, starch, trehalose and D-xylose. No acid production from D-glucitol, lactose or D-mannitol. Acetate, aconitate, benzoate, citrate, formate, malate, succinate and DL-tartrate are not utilized. Nitrate is reduced to nitrite, $\mathrm{H}_{2} \mathrm{~S}$ is produced, indole is not produced. Methyl red and Voges-Proskauer reactions are negative. Casein, aesculin, gelatin and potato starch are decomposed; adenine, hippurate, hypoxanthine, xanthine, Tween 80 and tyrosine are not decomposed. Urease activity is negative. $\mathrm{NaCl}$ in combination with $\mathrm{R}$ medium is well tolerated up to a concentration of $4 \%(\mathrm{w} / \mathrm{v})$. Good growth occurs at $28^{\circ} \mathrm{C}$, weak growth at $37^{\circ} \mathrm{C}$, no growth at $42^{\circ} \mathrm{C}$. Cells are susceptible to ampicillin $(10 \mu \mathrm{g})$, chloramphenicol $(30 \mu \mathrm{g})$, erythromycin $(15 \mu \mathrm{g})$, neomycin $(30 \mu \mathrm{g})$, oxytetracycline $(30 \mu \mathrm{g})$, penicillin G (2 IU) and rifampin $(2 \mu \mathrm{g})$. Susceptibility to polymyxin B (300 IU) is weakly expressed, no susceptibility to ciprofloxacin $(5 \mu \mathrm{g})$, gentamicin $(10 \mu \mathrm{g})$, kanamycin $(30 \mu \mathrm{g})$, lincomycin $(2 \mu \mathrm{g})$, nitrofuran $(300 \mu \mathrm{g})$, oxacillin $(5 \mu \mathrm{g})$, streptomycin $(10 \mu \mathrm{g})$ and sulfonamide. Tested by the API ZYM enzyme assay strain HKI $0122^{\mathrm{T}}$ is positive for phosphatase alkaline, esterase (C 4), esterase lipase (C 8), leucine arylamidase, cystine arylamidase, phosphatase acid, naphthol-AS-BI-phosphohydrolase, $\alpha$-galactosidase, $\beta$-galactosidase, $\alpha$-glucosidase, $N$-acetyl- $\beta$-glucosamidase, $\alpha$-mannosidase and $\alpha$-fucosidase, and negative for lipase (C 14), valine arylamidase, trypsin, 
chymotrypsin, $\beta$-glucuronidase and $\beta$-glucosidase. The peptidoglycan is of the A $4 \alpha$ type with an L-Lys $\leftarrow$ LGlu interpeptide bridge. The acyl type is acetyl. The fatty acid pattern is of the iso and anteiso branched type. The major menaquinone is $\mathrm{MK}-8\left(\mathrm{H}_{4}\right)$. The polar lipids are phosphatidylinositol, diphosphatidylglycerol and three unknown phospholipids. The $\mathrm{G}+\mathrm{C}$ content of the DNA is $71 \mathrm{~mol} \%$. Mycolic acids are absent. The habitat is soil. The type strain is HKI $0122^{\mathrm{T}}$ which has been deposited in the DSMZ as DSM $12333^{\mathrm{T}}$.

\section{ACKNOWLEDGEMENTS}

We acknowledge Xing Wang for providing the soil sample. We thank Christiane Weigel and Carmen Schult for excellent technical assistance.

\section{REFERENCES}

Altenburger, P., Kämpfer, P., Makristathis, A., Lubitz, W. \& Busse, H.-J. (1996). Classification of bacteria isolated from a medieval wall painting. $J$ Biotechnol 47, 39-52.

Collins, M. D. \& Jones, D. (1980). Lipids in the classification and identification of coryneform bacteria containing peptidoglycans based on 2,4-diaminobutyric acid. J Appl Bacteriol 48, 459-470.

Collins, M. D., Pirouz, T., Goodfellow, M. \& Minnikin, D. E. (1977). Distribution of menaquinones in actinomycetes and corynebacteria. J Gen Microbiol 100, 221-230.

De Soete, G. (1983). A least square algorithm for fitting additive trees to proximity data. Psychometrika 48, 621-626.

DSMZ (1998). Catalogue of Strains, 6th edn. Braunschweig: Deutsche Sammlung von Mikroorganismen und Zellkulturen.

Eppard, M., Krumbein, W. E., Koch, C., Rhiel, E., Staley, J. T. \& Stackebrandt, E. (1996). Morphological, physiological, and molecular characterization of actinomycetes isolated from dry soil, rocks, and monument surfaces. Arch Microbiol 166, 12-22.

Felsenstein, J. (1993). PHYLIP (Phylogenetic Inference Package) version 3.5.1. Seattle: Department of Genetics, University of Washington.

Frank, H., Rettenmeier, A., Weicker, H., Nicholson, G. J. \& Bayer, E. (1980). A new gas chromatographic method for determination of amino acid levels in human serum. Clin Chim Acta 105, 201-211.

Groth, I. \& Saiz-Jimenez, C. (1999). Actinomycetes in hypogean environments. Geomicrobiol $J$ 16, 1-8.

Groth, I., Schumann, P., Weiss, N., Martin, K. \& Rainey, F. A. (1996). Agrococcus jenensis gen. nov., sp. nov., a new genus of actinomycetes with diaminobutyric acid in the cell wall. Int $J$ Syst Bacteriol 46, 234-239.

Groth, I., Schumann, P., Rainey, F. A., Martin, K., Schuetze, B. \& Augsten, K. (1997a). Bogoriella caseilytica gen. nov., sp. nov., a new alkaliphilic actinomycete from a soda lake in Africa. Int $J$ Syst Bacteriol 47, 788-794.

Groth, I., Schumann, P., Rainey, F. A., Martin, K., Schuetze, B. \& Augsten, K. (1997b). Demetria terragena gen. nov., sp. nov., a new genus of actinomycetes isolated from compost soil. Int $J$ Syst Bacteriol 47, 1129-1133.

Groth, I., Vettermann, R., Schuetze, B., Schumann, P. \& SaizJimenez, C. (1999). Actinomycetes in Karstic caves of northern Spain (Altamira and Tito Bustillo). J Microbiol Methods 36, $115-122$
Jukes, T. H. \& Cantor, C. R. (1969). Evolution of protein molecules. In Mammalian Protein Metabolism, vol. 3, pp. 21-132. Edited by H. N. Munro. New York: Academic Press.

MacKenzie, S. L. (1987). Gas chromatographic analysis of amino acids as the $N$-heptafluorobutyryl isobutyl esters. $J$ Assoc Off Anal Chem 70, 151-160.

Maidak, B. L., Larsen, N., McCaughey, M. J., Overbeek, R., Olsen, G. J. \& Woese, C. R. (1997). The ribosomal database project. Nucleic Acids Res 25, 109-111.

Minnikin, D. E., Alshamaony, L. \& Goodfellow, M. (1975). Differentiation of Mycobacterium, Nocardia, and related taxa by thin-layer chromatographic analysis of whole-organism methanolysates. J Gen Microbiol 88, 200-204.

Minnikin, D. E., Collins, M. D. \& Goodfellow, M. (1979). Fatty acid and polar lipid composition in the classification of Cellulomonas, Oerskovia and related taxa. J Appl Bacteriol 47, 87-95.

Palleroni, N. J. (1997). Prokaryotic diversity and the importance of culturing. Antonie Leeuwenhoek 72, 3-19.

Rainey, F. A. (1998). The camels of the prokaryotic world. Abstracts of the 8th International Symposium on Microbial Ecology, Halifax, Canada, 9-14 August 1998.

Rainey, F. A., Ward-Rainey, N., Kroppenstedt, R. M. \& Stackebrandt, E. (1996). The genus Nocardiopsis represents a phylogenetically coherent taxon and a distinct actinomycete lineage: proposal of Nocardiopsaceae fam. nov. Int $J$ Syst Bacteriol 46, 1088-1092.

Rheims, H., Sproer, C., Rainey, F. A. \& Stackebrandt, E. (1996). Molecular biological evidence for the occurrence of uncultured members of the actinomycete line of descent in different environments and geographical locations. Microbiology 142, 2863-2870.

Rheims, H., Schumann, P., Rhode, M. \& Stackebrandt, E. (1998). Verrucosispora gifhornensis gen. nov., sp. nov., a member of the actinobacterial family Micromonosporaceae. Int J Syst Bacteriol 48, 1119-1127.

Schleifer, K. H. (1985). Analysis of the chemical composition and primary structure of murein. Methods Microbiol 18, 123-156.

Schleifer, K. H. \& Kandler, O. (1972). Peptidoglycan types of bacterial cell walls and their taxonomic implications. Bacteriol Rev 36, 407-477.

Schumann, P., Prauser, H., Rainey, F. A., Stackebrandt, E. \& Hirsch, P. (1997). Friedmanniella antarctica gen. nov., sp. nov., an LL-diaminopimelic acid-containing actinomycete from Antarctic sandstone. Int $J$ Syst Bacteriol 47, 278-283.

Stackebrandt, E., Fowler, V. J., Fiedler, F. \& Seiler, H. (1983). Taxonomic studies on Arthrobacter nicotianae and related taxa: Description of Arthrobacter uratoxydans sp. nov. and Arthrobacter sulfureus sp. nov. and reclassification of Brevibacterium protophormiae as Arthrobacter protophormiae comb. nov. Syst Appl Microbiol 4, 470-486.

Stackebrandt, E., Rainey, F. A. \& Ward-Rainey, N. L. (1997). Proposal for a new hierarchic classification system, Actinobacteria classis nov. Int $J$ Syst Bacteriol 47, 479-491.

Stead, D. E., Sellwood, J. E., Wilson, J. \& Viney, I. (1992). Evaluation of a commercial microbial identification system based on fatty acid profiles for rapid, accurate identification of plant pathogenic bacteria. $J$ Appl Bacteriol 72, 315-321.

Uchida, K. \& Aida, K. (1984). An improved method for the glycolate test for simple identification of the acyl type of bacterial cell walls. J Gen Appl Microbiol 30, 131-134. 
Waite, K., Hugghins, K., Battista, J. R., Ward-Rainey, N. \& Rainey, F. A. (1998). Isolation of members of the Geodermatophilus / Blastococcus group from desert soil exposed to ionizing radiation. Abstracts of the 8th International Symposium on Microbial Ecology, Halifax, Canada, 9-14 August 1998.

Yamada, K. \& Komagata, K. (1972). Taxonomic studies on coryneform bacteria. IV. Morphological, cultural, biochemical, and physiological characteristics. J Gen Appl Microbiol 18, 399-416.

Yokota, A., Takeuchi, M., Sakane, T. \& Weiss, N. (1993). Proposal of six new species of the genus Aureobacterium and transfer of Flavobacterium esteraromaticum Omelianski to the genus Aureobacterium as Aureobacterium esteraromaticum comb. nov. Int J Syst Bacteriol 43, 555-564. 